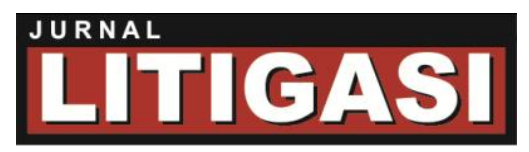

Available online at: http://ejournal.unpas.ac.id/index.php/litigasi

Litigasi, Vol. 17(1), 2016, 3256-3283

DOI: http://dx.doi.org/10.23969/litigasi.v17i1.97

\title{
UNDUE INFLUENCE SEBAGAI FAKTOR PENYEBAB CACAT KEHENDAK DILUAR KUHPERDATA, DALAM UPAYA MENGISI KEKOSONGAN HUKUM
}

\author{
N. Ike Kusmiati \\ Fakultas Hukum Universitas Pasundan Bandung, Jln. Lengkong Besar No. 68 - Bandung, Telp: 022- \\ 4262226, Email: ike.kusmiati@unpas.ac.id.
}

\begin{abstract}
ABSTRAK
Belum diaturnya penyalahgunaan keadaan sebagai faktor penyebab cacat kehendak dalam KUHPerdata Indonesia, perlu diantisipasi mengingat perkembangan kontrak terjadi begitu cepat dalam praktek. Bertemunya kata sepakat berupa persesuaian kehendak para pihak, tidak lagi terjadi secara seimbang, karena ada unsur yang mempengaruhi para pihak, baik secara ekonomis maupun secara kejiwaan. Untuk itu penting dimasukkannya unsur penyalahgunaan keadaan sebagai faktor yang menyebabkan cacad kehendak yang timbul dari Yurisprudensi di Belanda sebagai unsur yang keempat, disamping kekhilafan, paksaan maupun penipuan yang telah diatur dalam Pasal 1321 KUHPerdata. Hubungan penyalahgunaan keadaan sebagai faktor yang menyebabkan cacad kehendak terhadap terjadinya perjanjian, relevan karena perjanjian terjadi dengan adanya kata sepakat, dan untuk adanya sepakat diperlukan terjadinya persesuaian kehendak dari para pihak. Untuk itu kata sepakat menjadi dasar atas keabsahan kontrak. Namun adanya penyalahgunaan keadaan dalam kontrak menimbulkan kontrak menjadi dapat dibatalkan. Kedudukan penyalahgunaan keadaan sebagai faktor yang menyebabkan cacat kehendak dalam mengisi kekosongan hukum dalam sistem hukum kontrak di Indonesia, sangat penting, dimana selain belum ada pengaturan di Indonesia, juga karena sudah terjadi dalam praktek. Para pihak dalam kontrak seringkali disudutkan dengan kepentingan salah satu pihak, sehingga pihak lawan memberikan persetujuan dengan tidak sepenuh keyakinannya, karena tidak memiliki bargaining power yang seimbang.
\end{abstract}

Kata Kunci : Penyalahgunaan keadaan, Cacat Kehendak, Kontrak.

Copyright $@$ 2016, LITIGASI, p-ISSN: 0853-7100; e-ISSN: 2442-2274 
Available online at: http://ejournal.unpas.ac.id/index.php/litigasi

Litigasi, Vol. 17(1), 2016, 3256-3283

DOI: http://dx.doi.org/10.23969/litigasi.v17i1.97

\begin{abstract}
The misuse unarranged regulation of the state as a factor will cause defects in the Civil Code of Indonesia should be anticipated considering the development of contract occurs so fast in practice. The convergence of an agreement in the form of rapprochement will of the parties, no longer occur in a balanced manner, because there are elements that influence the parties, both economically and mentally. It is important to state the inclusion of substance abuse as factors that cause disability arising from the will of Jurisprudence in the Netherlands as the fourth element, in addition to negligence, coercion and deception that has been set out in Article 1321 of the Civil Code. Relationship abuse of circumstances as factors that led to the agreement will deform, relevant because the agreement occur with the agreement, and to the agreed required the conformity of the will of the parties. For that agreement became the basis for the validity of the contract. However, the abuse of state in the contract raises the contract can be canceled. Position misuse of state as the factor that causes defects will fill the void in the legal system of contract law in Indonesia, it is very important, where in addition there is no regulation in Indonesia, as well as already happens in practice. The parties to a contract are often cornered by the interests of one party, so that the opposing party does not provide consent with full conviction, because they do not have equal bargaining power.
\end{abstract}

Keywords: Abuse of state, Disability Will, Contracts.

Copyright @ 2016, LITIGASI, p-ISSN: 0853-7100; e-ISSN: 2442-2274 
Available online at: http://ejournal.unpas.ac.id/index.php/litigasi

Litigasi, Vol. 17(1), 2016, 3256-3283

DOI: http://dx.doi.org/10.23969/litigasi.v17i1.97

\section{PENDAHULUAN}

Di Indonesia berbicara masalah kontrak, tidak lepas dari

kehidupan manusia, yang senantiasa setiap saat selalu melakukan interaksi antara sesamanya, bahkan kontrak telah berkembang sampai ke jenjang lembagalembaga pembiayaan, bahkan kontrak telah berkembang kearah kontrak internasional. Hal ini dimungkinkan karena kecepatan dan perkembangan dunia bisnis, yang tarjadi secara global. Pertumbuhan ekonomi dan keuangan serta pertumbuhan interaksi secara nasional maupun internasional telah mempengaruhi perubahan dan pembaharuan hukum kontrak di bidang perjanjian. Hukum dan ekonomi merupakan penopang bagi pembangunan yang sedang berjalan, sehingga keduanya harus harmonis dan sinergi untuk tujuan melindungi kepentingan masyarakat. Oleh karena itu arah kebijakan politik hukum ekonomi harus mempunyai nilai agar tujuan hukum tersebut dapat terwujud.

Hukum dibuat untuk mengatur perilaku manusia agar tertib dan teratur, sehingga berbagai interaksi yang terjadi dapat berjalan dengan lancar. Kondisi ini menyebabkan banyaknya pendapat hukum yang berkembang di masyarakat, baik yang berdasar pada teori dan dapat dipertanggungjawabkan maupun yang berdasar pada pendapat yang asa-asalan. Oleh karena itu perlu didorong untuk melakukan upaya mengembalikan perdebatan pendapat hukum dengan memperhatikan prinsip-prinsip hokum. Begitu pula yang terjadi dalam kontrak, dimana kesepakatan memegang peranan penting di dalam kontrak para pihak. Perkembangan hukum kontrak saat ini diwarnai oleh makin tipisnya tabir pemisah antara dua system

Copyright $\odot$ 2016, LITIGASI, p-ISSN: 0853-7100; e-ISSN: 2442-2274 
hukum besar, yaitu common law dan civil law, dimana melibatkan hubungan bisnis antar Negara, khususnya kontrak komersial internasional yang telah membawa dampak perkembangan hukum kontrak yang mengadopsi asas-asas universal yang berkembang dalam praktek. Dokumen-dokumen hukum dalam bentuk model law, legal guide, prinsip hukum umum, atau standar kontrak, yang dikeluarkan oleh lembaga atau organisasi internasional turut memacu proses harmonisasi hukum kotrak, misalnya UNCITRAL (United Nation Conferenca onInternational Trade Law) atau dengan CSIG (Contracts for the International Sales of Goods), atau UNIDROIT (International Institute for the Unification of Private Law) (Agus yudha Hernoko, 2009). Menurut Arthur S. Kartkamp reformasi hukum perdata Belanda yang diketuai oleh Meijers dari Universitas Leidn yang telah berhasil menyusun ulang Burgerlijk Wetboek ke dalam sistematika baru NBW menjadi Sembilan buku yang terkait dengan hukum kontrak, yaitu :

(1)Buku III tentang Hukum Harta Kekayaan pada Umumnya (Algemeen Gedeelte vanHet Vermogensrecht

(2)Buku V tentang Hak-Hak Kebendaan, (Zakelijk Rechten)

(3) Buku VI tentang Ketentuan umum Hukum Perikatan (Algemeen Gedeelte van HetVerbintenissenrecht) dan

(4)Buku VII tentang Kontrak Khusus (Bijzondere Overeencomsten)

Substansi New Burgerlijk Wetboek telah benyak mengalami perubahan fundamental dengan substansi yang disesuaikan menurut kebutuhan masyarakat modern, termasuk diterimanya system hukum lain. Contoh pengaruh common 
law dalam kandungan substansi NBW adalah doktrin penyalahgunaan keadaan atau misbruik vanomstandigheden (undue influence). Mengacu pada reformasi NBW di Belanda, maka dirasakan perlunya BW Indonesia segera direfisi. Kandungan doktrin penyalahgunaan keadaan ini telah membawa perkembangan hukum kontrak Indonesia modern yang diakomodir dari commom law system.

Dengan asas konsensual, perjanjian sudah terjadi sejak detik terjadinya kata sepakat diantara para pihak. Bahkan kesepakatan ini menjadi pilar penting dalam upaya terjadinya kontrak dalam hukum perjanjian di Indonesia. Asas konsensual juga menjadi asas yang sifatnya universal yang berlaku sebagai asas umum diberbagai negara-negara di dunia. Syarat sahnya perjanjian di Indonesia, sebagaimana dituangkan dalam Pasal 1320 KUHPerdata bahwa syarat syahnya perjanjian adalah, adanya :

1. Kesepakatan

2. Kecakapan

3. Hal tertentu dan

4. Objek yang halal

Apabila syarat kesatu dan kedua tidak dipenuhi, maka akibat hukumnya adalah perjanjian itu menjadi dapat dibatalkan. Artinya para pihak harus memenuhi unsur ini, dimana kesepakatan maupun unsur kecakapan harus dipenuhi. Dapat dibatalkan membawa konsekuensi, bahwa perjanjian itu telah membawa akibat terhadap para pihak bahwa terhadap perjanjiannya sejak adanya gugatan atau putusan pengadilan terhadap suatu perjanjian itu menjadi dapat dibatalkan, karena

Copyright @ 2016 , LITIGASI, p-ISSN: 0853-7100; e-ISSN: 2442-2274 
adanya gugatan atau putusan pengadilan tersebut, dapat dimintakan pembatatalan (cancelling) oleh salah satu pihak, misalnya untuk yang belum cakap menurut hukum diajukan oleh orang tua atau walinya, atau ia sendiri apabila sudah cakap. Sedangkan bila syarat ketiga dan keempat tidak dipenuhi, maka perjanjian itu akibatnya batal demi hukum. Ini membawa konsekuenksi bahwa dari sejak semula kontrak itu menjadi tidak membawa akibat hukum apa-apa, karena kontrak ini telah bertentangan dengan udang-undang, ketertiban umum maupun kesusilaan. Jadi secara yuridis dari semula tidak ada suatu perjanjian dan tidak ada pula suatu perikatan antara orang-orang yang bermaksud membuat perjanjian (R.Subekti, 2010) Dengan demikian tidaklah dapat pihak yang satu menuntut pihak lain di depan hakim, karena dasar hukumnya tidak ada.

Begitu pula berkaitan dengan kesepakatan, perjanjian di Indonesia telah mengatur tentang faktor-faktor yang menyebabkan cacat kehendak sebagaimana diatur dalam Pasal 1321 KUHPerdata, bahwa unsur kehilafan, paksaan dan penipuan merupakan unsur penyebab kesepakatan menjadi cacat.

Namun di dalam praktek terjadi persoalan ketika terjadi peristiwa yang dapat dikategorikan sebagai pengalahgunaan keadaan (Undue Influence) sebagai unsur yang dapat dimasukkan ke dalam faktor-faktor yang menyebabkan cacat kehendak. Adanya penyalahgunaan keadaan dalam kontrak menyebabkan kontrak itu menjadi dapat dibatalkan karena unsur subjektif yang dilanggar dalam kontrak. Unsur ini membawa akibat hukum terhadap para pihak yang menandatangani kontrak.

Copyright $\odot$ 2016, LITIGASI, p-ISSN: 0853-7100; e-ISSN: 2442-2274 
Available online at: http://ejournal.unpas.ac.id/index.php/litigasi

Litigasi, Vol. 17(1), 2016, 3256-3283

DOI: http://dx.doi.org/10.23969/litigasi.v17i1.97

Hal ini terjadi dalam praktek, misalnya terjadi peristiwa di bank pada saat menentukan bunga bank seolah-olah itu adalah pilihan yang sulit bagi pihak lawan untuk menyetujui kontrak tersebut bahwa bunga itu misalnya terlalu besar melebihi dari ketentuan undang-undang, atau dalam hal perparkiran juga terjadi persoalan, dimana dalam pusat perparkiran terdapat klausul atau janji bahwa kendaraan yang hilang diluar tanggungjawab pelaku usaha. Ini jelas suatu keadaan sebagai pilihan yang sulit, walaupun ada kata-kata atau janji atau klausul seperti itu yang mempunyai kendaraan tetap saja parkir di situ. Atau terjadi juga dalam kontrak leasing, dengan adanya klausul, motor harus dieksekusi pada saat lessee tidak melakukan pembayaran dengan tidak memperhatikan besarnya pembayaran yang dilakukan lessee. Ini juga pilihan sulit bagi pihak lawan. Oleh karenanya semua perjanjian tersebut di atas, merupakan pilihan yang sulit bagi para pihak terutama bagi debitur yang sacara sepihak dihadapkan pada pilihan yang sulit untuk dipilih karena posisi tawar berada pada pihak yang lemah dibandingkan dengan posisi tawar kreditur yang lebih tinggi. Inilah posisi kreditur sangat menentukan dan secara ekonomis labih menguntungkan kedudukannya, ketimbang debitur.

Dalam kaitan ini masalah penyalahgunaan keadaan penting untuk dibahas dalam penulisan ini karena merupakan faktor yang menyebabkan cacat kehendak bagi para pihak yang mana dalam hukum kontrak berdasarkan KUHPerdata belum diatur, dan terjadi dalam praktek. Perjanjian dalam arti yuridis terjadi karena penawaran oleh pihak yang satu dan yang diterima oleh pihak yang lain, dimana saat penerimaan adalah saat terjadinya perjanjian. Penawaran dan penerimaan

Copyright @ C 2016, LITIGASI, p-ISSN: 0853-7100; e-ISSN: 2442-2274 
Available online at: http://ejournal.unpas.ac.id/index.php/litigasi

Litigasi, Vol. 17(1), 2016, 3256-3283

DOI: http://dx.doi.org/10.23969/litigasi.v17i1.97

harus berisi pernyataan kehendak baik dari yang menawarkan maupun lawannya bahwa disetujui untuk mengadakan perjanjian. Dengan demikian telah terpenuhi persyaratan yang terpenting perjanjian yang oleh Pasal 1320 KUHPerdata disyaratkan untuk sahnya perjanjian. Sebagaimana pentingnya ada persesuai kehendak diantara para pihak. Apabila pernyataan kehendak itu tidak ada, maka, perjanjian itu juga tidak ada. Dalam praktek terjadi yaitu bila pernyataan kehendak tidak selalu menggambarkan kehendak pihak yang sesungguhnya. Satu pihak dapat dikelabui oleh pihak lain tentang isi kontrak yang akan diadakan, yang mempengaruhi kehendaknya, yang dalam hal ini disebut kekhilafan. Mungkin juga satu pihak oleh pihak lain diberi informasi yang salah tentang isi perjanjian dalam hal ini disebut penipuan, atau suatu pihak dipaksa oleh pihak lain untuk memberi pernyataan kehendak yang menyebabkan perjanjian itu terjadi karena paksaan. Hal ini diatur dalam Pasal 1321 KUHPerdata. Dalam ilmu hukum disebut dengan cacad kehendak klasik karena selalu berhubungan dengan cacad dalam pembentukan kehendak yang didasarkan pada pernyataan kehendak.

Merupakan syarat penting juga bahwa perjanjian tidak boleh bertentangan dengan undang-undang, kebiasaan yang baik dan ketertiban umum sebagaimana ditetapkan dalam Pasal 1335-1337 KUHPerdata. KUHPerdata tidak mengenal ketentuan perundang-undangan yang tegas mengenai penyalahgunaan keadaan. Apabila seorang hakim berpendapat bahwa pada suatu peristiwa tertentu terjadi penyalahgunaan keadaan, maka dilihatnya adanya keadaan yang bertentangan dengan kebiasaan yang baik dan berdasarkan hal itu menganggap perjanjian tidak

Copyright @ 2016 , LITIGASI, p-ISSN: 0853-7100; e-ISSN: 2442-2274 
Available online at: http://ejournal.unpas.ac.id/index.php/litigasi

Litigasi, Vol. 17(1), 2016, 3256-3283

DOI: http://dx.doi.org/10.23969/litigasi.v17i1.97

berlaku untuk sebagian atau seluruhnya (Sudikno Mertokusumo, 1987). Akibat hukum yang dikaitkan dengan Pasal 1335 KUHPerdata bahwa perjanjian tanpa sebab yang dibolehkan itu tidak mempunyai kekuatan. Artinya perjanjian itu batal, yang berarti perjanjian itu secara yuridis dianggap tidak pernah ada atau tidak mempunyai akibat hukum apapun.

Dalam yurisprudensi ajaran tentang sebab yang tidak dibolehkan digunakan sebagai penyelesaian dalam peristiwa-peristiwa tentang penyalahgunaan keadaan dapat bertindak demi keadilan. Sebagai contoh dalam peristiwa BOVAG II Putusan HR 11 Januari 1957 Max Mozes mereparasikan mobilnya kepada Firma Uijting en Smits di Oss bahwa percobaan yang dilakukan oleh montir pada perusahaan bengkel tersebut menabrak dua orang gadis. Bank Central Werkgevers di Amesterdam membayar ganti rugi kepada para korban dan menuntut balik perusahaan bengkel maupun Mozes masing-masing untuk seluruhnya dengan catatan bahwa bila seseorang membayar, maka yang lain dibebaskan. Uijting en Smits meminta agar Mozes menanggungnya dengan alasan bahwa "penitipan, pemeliharaan, reparasi dan mengendarai kendaraan bermotor hanya terjadi dengan ketentuan tegas, bahwa mereka tidak bertanggungjawab atas pencurian, kehilangan, musnahnya barang atau ketugian apapun, kecuali bila ternyata ada kekurangan yang serius dari pengurus perusahaan secara pribadi".

Rechtbank s'Hertogenbosch sebagai pengadilan tingkat pertama menolak tuntutan Uijting en Smits, karena bukti yang diminta bahwa papan Bocagclausula dipasang dengan jelas dalam garasi tidak dapat diajukan. Uijting Smits terhadap

Copyright @ C 2016, LITIGASI, p-ISSN: 0853-7100; e-ISSN: 2442-2274 
putusan ini mengajukan banding pada Hof yang mempertimbangkan bahwa "Apabila harus diterima, klausula Bovag harus dianggap termasuk dalam isi perjanjian antara kedua belah pihak, klausula penanggungan di dalamnya tidak berlaku, seperti perjanjian dengan sebab yang tidak dibolehkan. Kalusula ini harus dinilai sebagai perjanjian yang bertentangan dengan kebiasaan yang baik, dan bertentangan dengan ketertiban umum, yang di dasarkan pada cara terjadinya bagian perjanjian, juga berhubungan dengan isi dan maksud klausula yang bersangkutan. Klausula ini berisi beban yang terlalu berat bagi pengendara mobil, yang dibebani dengan kewajiban untuk menanggung akibat-akibat perbuatan yang tidak dilakukannya. Uijting Smits kemudian ajukan kasasi dengan ajukan alasan bahwa cara terjadinya perjanjian tidak menyentuh sebabnya.

Hoge Raad mengambil alih pendirian Hof dengan pertimbangan bahwa suatu perjanjian yang merugikan dapat terjadi tanpa sebab yang dibolehkan berhubungan dengan pengaruh-pengaruh istimewa yang berlaku pada saat perjanjian dibuat, yaitu bila pihak yang dirugikan telah menerima beban yang tidak seimbang beratnya dibawah tekanan keadaan, yang disalahgunakan oleh pihak lawan, dan titik tolak ini sendiri adalah tepat. Oleh karena Hof memutus terlalu umum, maka Hoge Raad membatalkan putusan Hof dan mengembalikan perkaranya kepada Hof agar dengan memperhatikan putusan Hoge Raad memutuskan secara definitif. Hoge Raad dalam prosedur ini untuk pertama kali mengakui penyalahgunaan keadaan sebagai dasar pembatalan perjanjian (Sudikno Mertokusumo, 1987).

Copyright @ C 2016, LITIGASI, p-ISSN: 0853-7100; e-ISSN: 2442-2274 
Available online at: http://ejournal.unpas.ac.id/index.php/litigasi

Litigasi, Vol. 17(1), 2016, 3256-3283

DOI: http://dx.doi.org/10.23969/litigasi.v17i1.97

Berdasarkan uraian pada latar belakang masalah tersebut, penulis dapat merumuskan identifikasi masalah sebagai berikut : Bagaimana hubungan penyalahgunaan keadaan sebagai faktor yang menyebabkan cacad kehendak terhadap terjadinya kontrak dan bagaimana kedudukan penyalahgunaan keadaan sebagai faktor yang menyebabkan cacad kehendak dalam upaya mengisi kekosongan hukum dalam sistem Hukum Perjanjian di Indonesia ?

\section{PEMBAHASAN}

A. Hubungan penyalahgunaan keadaan sebagai faktor yang menyebabkan cacad kehendak terhadap terjadinya perjanjian, adalah sangat relevan bahwa suatu perjanjian terjadi dalam keadaan-keadaan tertentu tidak mempunyai pengaruh atas dibolehkan atau tidaknya sebab penjanjian. Apa yang ingin dicapai oleh para pihak ternyata dibawah pengaruh penyalahgunaan keadaan, yaitu merugikan salah satu pihak. Maksud dan tujuannya adalah merugikan salah satu pihak, sehingga ini tidak diperbolehkan karena bertentangan dengan ketertiban umum dan kebiasaan sebagaimana yang dijelaskan oleh Pasal 1335 jo Pasal 1337 KUHPerdata. Hanya bila bertitik tolak pada asas iustum pretium dapat ditentukan bahwa kerugian yang tidak pantas terhadap salah satu pihak menyebabkan perjanjian itu tidak dibolehkan. Bahwa pengalahgunaan keadaan tidak hanya berisi prestasi yang tidak seimbang, tetapi juga terhadap keadaankeadaan yang berperan pada terjadinya kontrak, yaitu menikmati keadaan orang lain tidak menyebabkan isi kontrak atau maksudnya menjadi tidak

Copyright @ 2016 , LITIGASI, p-ISSN: 0853-7100; e-ISSN: 2442-2274 
Available online at: http://ejournal.unpas.ac.id/index.php/litigasi

Litigasi, Vol. 17(1), 2016, 3256-3283

DOI: http://dx.doi.org/10.23969/litigasi.v17i1.97

dibolehkan, tetapi menyebabkan kehendak yang disalahgunakan menjadi tidak bebas. Penyalahgunaan keadaan masalahnya adalah mengenai keunggulan pihak yang satu terhadap pihak yang lain. Keunggulan ini dapat dibagi menjadi dua, yaitu keunggulan yang bersifat ekonomis dan keunggulan kejiwaan. Persyaratan-persyaratan dalam penyalahgunaan keunggulan ekonomis yaitu adanya kelaziman kerugian yang jelas secara konkrit dapat dinyatakan dengan uang. Apabila dalam kontrak tertentu diminta harga atau bunga yang terlalu tinggi. Dalam hubungan kontrak dapat dilihat adanya keunggulan pada salah satu pihak terhadap yang lain. Ini menyebabkan pihak dari yang secara keunggulan ekonomis berkuasa untuk mendapatkan prestasi tertentu yang sangat dibutuhkan pihak lawan, sekalipun kontrak itu merugikan, keadaan ini yang memaksanya berbuat demikian. Misalnya hubungan majikan dengan pekerja, penyewa dengan yang menyawakan, peminjam dengan yang meminjamkan dan sebagainya. Penyalahgunaan kedudukan ekonomis yang lebih kuat sering tampak pada kontrak-kontrak baku, dimana terjadinya dipengaruhi oleh penyalahgunaan keadaan. Hal ini sering berhubungan dengan klausula eksonerasi, dimana pertanggungjawaban pihak yang ekonominya lebih kuat bergeser ke pihak yang ekonominya lemah. Penyalahgunaan keunggulan ekonomis, oleh Ruitinga terletak pada "inequality of bargaining power" dimana pihak yang lebih lemah dan pihak yang secara ekonomis lebih berkuasa menyalahgunakannya dan memaksakan kehendaknya dari perjanjian yang memberinya keuntungan yang tidak seimbang. Dengan demikian dapat 
Available online at: http://ejournal.unpas.ac.id/index.php/litigasi

Litigasi, Vol. 17(1), 2016, 3256-3283

DOI: http://dx.doi.org/10.23969/litigasi.v17i1.97

dikatakan bahwa dalam penyalahgunaan keadaan ekonomis, satu pihak harus mempunyai keunggulan ekonomis terhadap yang lain dan pihak lain terpaksa mengadakan perjanjian.

Persyaratan untuk adanya penyalahgunaan keunggulan kejiwaan, terjadi apabila salah satu pihak menyalahgunakan ketergantungan atau keadaan jiwa yang istimewa dari pihak lawan, seperti hubungan antara orang tua dan anak, suami dan istri, dokter dan pasien, dan lain sebagainya. Pihak yang dirugikan dalam posisi ini membuat ia sangat mudah dipengaruhi yang disebabkan oleh ganggguan jiwa, usia lanjut, tidak berpengalaman, kurang pengetahuan dan sebagainya. Berdasarkan hubungan kepercayaan atau keadaan yang dapat mempengaruhi, maka pihak yang satu mempunyai keunggulan kejiwaan terhadap pihak yang lain. Pihak yang dirugikan dibujuk untuk melakukan perbuatan yang sama sekali tidak dikehendakinya. Pada umumnya tidak dapat menggambarkan akibat perbuatan itu dan tidak menyadari keadaannya (Sudikno Mertokusumo, 1987).

Biasanya ini disebabkan oleh posisi tawar yang tidak seimbang, dan berat sebelah karena tidak ada pilihan dari pihak yang dirugikan disertai dengan klausula dalam kontrak yang sangat tidak adil, sehingga memberikan keuntungan yang tidak wajar bagi pihak lainnya. Menurut Rosa Agustina, pengadilan Indonesia juga menerapkan doktrin pengaruh tidak seimbang, bahwa jika salah satu pihak berkedudukan dominan, maka ia dapat menyalahgunakan kedudukannya itu dan mendorong pihak lain masuk ke

Copyright @ C 2016, LITIGASI, p-ISSN: 0853-7100; e-ISSN: 2442-2274 
Available online at: http://ejournal.unpas.ac.id/index.php/litigasi

Litigasi, Vol. 17(1), 2016, 3256-3283

DOI: http://dx.doi.org/10.23969/litigasi.v17i1.97

dalam kontrak. Dominasi ini dapat bersifat psikologis atau ekonomis. Juga menurut Johannes Gunawan indikasi adanya pengaruh tidak seimbang dapat dijumpai dalam perjanjian baku, dimana :

1. Isi kontrak baku tidak masuk akal, tidak patut, bertentangan dengan kemanusiaan (unfair contract term);

2. Pihak penutup kontrak baku dalam keadaan tertekan;

3. Pihak penutup kontrak baku tidak memiliki pilihan lain, kecuali menerima isi kontrak baku walaupun dirasakan memberatkan;

4. Hak dan kewajiban para pikah tidak seimbang.

Sedangkan menurut Munir Fuady bahwa kontrak yang mengandung unsur pengaruh tidak pantas memiliki unsur-unsur sebagai berikut :

1. Diskusi untuk kontrak dibuat pada waktu-waktu yang tidak pantas atau tidak biasanya

2. Diskusi atau penandatanganan kontrak pada tempat yang tidak lazim

3. Desakan yang intens bahwa bisnis harus dilaksanakan dengan segera

4. Penekanan yang tidak proporsional terhadap konsekuensi dari keterlambatan penandatanganan atau keterlambatan melaksanakan kontrak.

5. Penggunaan banyak penekanan/pembujuk terhadap pihak lainnya

6. Digiring agar pihak lainnya tidak sempat atau tidak dapat berhubungan dengan penasihat finansial atau penasihat hukum (Ahmad Fikri Assegaf, 2014).

Copyright @ 2016 , LITIGASI, p-ISSN: 0853-7100; e-ISSN: 2442-2274 
Available online at: http://ejournal.unpas.ac.id/index.php/litigasi

Litigasi, Vol. 17(1), 2016, 3256-3283

DOI: http://dx.doi.org/10.23969/litigasi.v17i1.97

Syarat yang berkaitan erat agar suatu perjanjian dapat mengikat pihakpihaknya adalah syarat kesepakatan oleh kedua pihak. Syarat ini merupakan asas yang terdapat dalam perjanjian, yaitu asas konsensualisme yang mengedepankan perjanjian terbentuk karena adanya pertemuan kehendak dari para pihak. Perjanjian pada pokoknya dapat dibuat bebas, tidak terikat bentuk, dan tercapai tidak secara formil, tetapi cukup melalui konsensus belaka. Hal ini sebagaimana ditegaskan dalam Pasal 1320 KUHPerdata bahwa kesepakatan oleh para pihak, yang berada dalam perjanjian, mengikat bagi para pihak. Sepakat oleh mereka yang mengikatkan diri adalah hal yang esensial dalam perjanjian, sehingga dengan kata sepakat tersebut, suatu perjanjian memenuhi keabsahan sehingga dapat mengikat pihak-pihak yang membuatnya. Sepakat juga berlaku karena kedua belah pihak sama-sama setuju hal-hal yang pokok dari suatu perjanjian yang diadakan. Pihak-pihak tersebut menghendaki suatu hal pokok yang bersifat timbal balik disekati oleh para pihak. Oleh karenanya terjadilah persesuaian kehendak yang dapat dilakukan dengan cara :

1. Bahasa yang sempurna dan tertulis

2. Bahasa yang sempurna secara lisan

3. Bahasa yang tidak sempurna asal dapat diterima oleh pihak lawan

4. Bahasa isyarat asal dapat diterima oleh pihak lawannya

5. Diam atau membisu asal dipahami atau diterima pihak lawan.

Berdasarkan uraian tersebut di atas, bahwa terjadinya kesepakatan dapat terjadi secara tertulis maupun tidak tertulis. Dengan adanya kesepakatan

Copyright $\odot$ 2016, LITIGASI, p-ISSN: 0853-7100; e-ISSN: 2442-2274 
Available online at: http://ejournal.unpas.ac.id/index.php/litigasi

Litigasi, Vol. 17(1), 2016, 3256-3283

DOI: http://dx.doi.org/10.23969/litigasi.v17i1.97

atau meeting point antara kedua belah pihak. Kata sepakat ini seringkali menjadi dasar atas berlakunya perjanjian, dan satu pihak dapat menuntut kewajiban dari pihak lain berdasarkan perjanjian tersebut. Untuk menentukan saat terjadinya perjanjian dalam arti adanya persesuaian kehendak dari para pihak ada beberapa teori, yaitu :

1. Teori Ucapan (uitingstheory), menurut teori ini kesepakatan (toesteming) terjadi pada saat pihak yang menerima penawaran menyatakan bahwa ia menerima penawaran tersebut. Jadi ini dilihat dari pihak yang menerima, yaitu pada saat baru menjatuhkan ballpoint untuk menyatakan menerima.

2. Teori Pengiriman (verzendtheory) Menurut teori ini kesepakatan terjadi apabila pihak yang menarima penawaran mengirimkan telegram. Teori ini sangan teoritis karena menganggap terjadinya kesepakatan secara otomatis.

3. Teori Pengetahuan (vernemingstheory) Menurut teori ini kesepakatan terjadi apabila pihak yang menawarkan mengetahui adanya acceptatie (penerimaan) tetapi penerimaan tersebut belum diterimanya.

4. Teori Penerimaan (onvangstheory) Menurut teori ini kesepakatan terjadi pada saan pihak yang menawarkan menerima langsung jawaban dari pihak lawan.

Dengan demikian momentum terjadinya perjanjian adalah pada saat terjadinya persesuaian antara pernyataan dan kehendak antara kreditur dan debitur, namun dapam praktek sering terjadi antara pernyataan dan kehendak tidak sesuai. Untuk menjawab ini ada tiga teori, yaitu :

Copyright @ C 2016, LITIGASI, p-ISSN: 0853-7100; e-ISSN: 2442-2274 
Available online at: http://ejournal.unpas.ac.id/index.php/litigasi

Litigasi, Vol. 17(1), 2016, 3256-3283

DOI: http://dx.doi.org/10.23969/litigasi.v17i1.97

1. Teori Kehendak (wilstheory) menurut teori ini perjanjian terjadi apabila ada persesuaian antara kehendak dan pernyataan. Apabila terjadi ketidakwajaran kehendaklah yang menyebabkan terjadinya perjanjian.

2. Teori Pernyataan (verclaringstheory) menurut teori ini kehendak merupakan proses batiniah yang tidak diketahui orang lain, akan tetapi yang menyebabkan terjadinya perjanjian adalah pernyataan. Apabila terjadi perbedaan antara kehendak dan pernyataan, perjanjian tetap terjadi.

3. Teori Kepercayaan (vertrouwnstheory) menurut teori ini tidak setiap pernyataan menimbulkan perjanjian, tetapi pernyataan yang menimbulkan kepercayaan saja yang menimbulkan perjanjian. Kepercayaan di sini artinya pernyataan yang benar-benar dikehendaki oleh para pihak, sesuai yang diperjanjikan.

Menurut Pasal 1321 KUHPerdata kata sepakat yang mengabsahkan perjanjian dikecualikan dalam keadaan tertentu yaitu :

1. Kekhilafan (dwaling)

Suatu perjanjian mengandung unsur kekhilafan apabila para pihak, baik secara bersama-sama ataupun masing-masing telah dipengaruhi oleh pandangan atau kesan yang ternyata tidak benar. Hal ini dilakukan tanpa sepengetahuan atau disadari oleh masing-masing pihak tersebut. Pada prinsipnya Pasal 1322 KUHPerdata memiliki dua ketentuan pokok. Pertama kekhilafan bukanlah alasan untuk membatalkan perjanjian. Kedua terdapat pengecualian terhadap perjanjian tersebut, sehingga pembatalan

Copyright @ 2016 , LITIGASI, p-ISSN: 0853-7100; e-ISSN: 2442-2274 
Available online at: http://ejournal.unpas.ac.id/index.php/litigasi

Litigasi, Vol. 17(1), 2016, 3256-3283

DOI: http://dx.doi.org/10.23969/litigasi.v17i1.97

perjanjian tetap dapat dilakukan karena kekhilafan tertentu. Objek kekhilafan yang dikecualikan di sini menurut KUHPerdata terdiri dari bebarapa hal :

a. Kekhilafan terhadap objek barang, yaitu kekhilafan yang terjadi atas objek dari perjanjian, sehingga terjadi kesalahfahaman terhadap objek perjanjian. Bagi para pihak objek perjanjian yang sesungguhnya tidak sesuai dengan yang diperjanjikan dalam perjanjian.

b. Kekhilafan terhadap subjek perjanjian, yaitu kesalahan menyangkut pihak yang dimaksud dalam perjanjian. Misalnya terjadi karena kesamaan nama, alamat dan lain-lain, sehingga pihak yang dimaksud tertukar.

2. Paksaan (geweld) diatur dalam Pasal 1323 KUHPerdata bahwa perjanjian dapat dibatalkan apabila terjadi paksaan, baik dari pihak tertentu maupun dari pihak ketiga, sedangkan pengertian paksaan, diatur dalam Pasal 1324 KUHPerdata yaitu apabila sebuah perbuatan dilakukan sedemikian rupa sehingga mengakibatkan ketakutan pada orang yang melalukan perjanjian dan rasa terancam terhadap dirinya atau kekayaannya secara terang dan nyata. Dengan demikian makna paksaan adalah kekerasan jasmani atau ancaman mempengaruhi kejiwaan yang menimbulkan ketakutan pada orang lain, sehingga dengan sangat terpaksa membuat suatu perjanjian (Wawan Muhwan Hariri, 2011)

Copyright @ 2016 , LITIGASI, p-ISSN: 0853-7100; e-ISSN: 2442-2274 
Available online at: http://ejournal.unpas.ac.id/index.php/litigasi

Litigasi, Vol. 17(1), 2016, 3256-3283

DOI: http://dx.doi.org/10.23969/litigasi.v17i1.97

3. Penipuan (bedrog) diatur dalam Pasal 1328 KUHPerdata sebagai perbuatan yang juga dapat membatalkan perjanjian yaitu apabila terjadi tipu muslihat terhadap salah satu pihak, yang sudah pasti tidak akan sepakat apabila tahu senyatanya isi perjanjian tersebut. Penipuan ini pada prinsipnya harus dibuktikan dan tidak bisa dipersangkakan. Hal ini sebagaimana dikemukakan oleh Munir Fuady bahwa konsekuensi hukum jika syarat kesepakatan kehendak tidak terpenuhi dalam suatu kontrak, sama halnya tidak terpenuhinya syarat kewenangan membuat perikatan. Oleh karenanya bila syarat kesepakatan kehendak ini tidak terpenuhi, maka akibat hukumnya adalah "dapat dibatalkan" (vernietigebaar voidable) (Ahmad Fikri Assegaf, 2014). Dengan demikian betapa pentingnya hubungan antara penyalahgunaan keadaan terhadap terjadinya perjanjian dalam praktek di Indonesia sangat penting, karena perjanjian akan dapat dilaksanakan bila tidak ada faktor yang mempengaruhinya bagi berjalannya keinginan atau kesesuaian kehendak para pihak berdasarkan pertemuan kehendak para pihak secara seimbang.

B. Kedudukan penyalahgunaan keadaan sebagai faktor yang menyebabkan cacat kehendak dalam upaya mengisi kekosongan hukum dalam sistem hukum perjanjian di Indonesia adalah ada pada syarat sahnya perjanjian dalam Pasal 1320 KUHPerdata, yaitu harus adanya kata sepakat diantara para pihak. Apabila terjadi "pengaruh yang tidak pantas" atau "cacat" pada unsur kesepakatan kehendak, karena pihak yang dipengaruhi tersebut sebenarnya

Copyright $\odot$ 2016, LITIGASI, p-ISSN: 0853-7100; e-ISSN: 2442-2274 
Available online at: http://ejournal.unpas.ac.id/index.php/litigasi

Litigasi, Vol. 17(1), 2016, 3256-3283

DOI: http://dx.doi.org/10.23969/litigasi.v17i1.97

tidak memberi persetujuan dengan sepenuh keyakinannya, karena secara hukum kontrak yang bersangkutan berstatus "dapat dibatalkan". Dalam perkembangannya keabsahan berkontrak hanya dapat mencapai tujuannya bila para pihak mempunyai "bargaining power" yang seimbang. Apabila salah satu pihak lemah, maka posisi tawar pihak yang memiliki bargaining power lebih kuat dapat memaksakan kehendaknya untuk menekan pihak lain, demi keuntungan diri sendiri. Syarat-syarat atau ketentuan-ketentuan dalam kontrak, akan melanggar aturan-aturan yang adil dan layak, dimana dalam kenyataannya para pihak tidak selalu memiliki bargaining power yang seimbang, sehingga negara turut campur untuk melindungi pihak yang lamah. Ditinjau dari segi perkembangan Hukum Perdata campur tangan pemerintah merupakan pergeseran Hukum Perdata ke dalam proses pemasyarakatan (veemaatschappelijking) untuk kepentingan umum. Hal ini sesuai dengan UUD 1945 yang telah melepaskan diri dari konsepsi hukum yang liberal dan menganut konsepsi hukum yang Pancasilais. Di dalam konkretonya Hukum Perdata khususnya hukum kontrak mencari bentuk baru untuk memenuhi tuntutan itu antara lain melalui campur tangan pemerintah, sehingga materimateri yang menyangkut kepentingan umum akan mendapat perlindungan hukum, yaitu dengan memperbanyak peraturan-peraturan yang sifatnya memaksa (dwingen recht) dalam upaya melindungi pihak yang lemah (Agus Yudha Hernoko, 2009).

Copyright @ 2016 , LITIGASI, p-ISSN: 0853-7100; e-ISSN: 2442-2274 
Available online at: http://ejournal.unpas.ac.id/index.php/litigasi

Litigasi, Vol. 17(1), 2016, 3256-3283

DOI: http://dx.doi.org/10.23969/litigasi.v17i1.97

Dapat dilihat dalam praktek terjadinya penggerogotan terhadap asas kebebasan berkontrak betapa lemahnya perlindungan terhadap pihak yang kedudukannya sebagai pihak dalam kontrak hanya menerima saja dalam keadaan terpaksa maupun akibat pengaruh tidak pantas. Setiawan menyatakan bahwa pembatasan kebebasan berkontrak dipengaruhi oleh :

1. Berkembangnya doktrin itikad baik

2. Berkembangnya doktrin penyalahgunaan keadaan

3. Makin banyaknya kontrak baku

4. Berkembangnya hukum ekonomi.

Sedangkan Purwahid Patrik melihat pembatasan kebebasan berkontrak disebabkan diantaranya :

1. Berkembangnya ekonomi yang membentuk persekutuan dagang, badanbadan hukum atau perseroan dan golongan-golongan masyarakat lain.

2. Terjadinya pemasyarakatan keinginan adanya keseimbangan antar individu dan masyarakat yang setuju kepada keadilan sosial.

3. Timbulnya formalisme perjanjian.

Terlepas dari tereduksinya supremasi asas kebebasan berkontrak, keseimbangan para pihak dalam berkontrak merupakan konsep dasar yang tidak dapat ditawar, karena harus ada dalam diri para pihak itu pemahaman dan penghormatan terhadap hak masing-masing dalam kontrak (Agus Yudha Hernoko, 2009). Oleh karenanya dapat dipahami bahwa perkembangan asas kebebasan berkontrak cenderung mengarah pada ketidakseimbangan para 
Available online at: http://ejournal.unpas.ac.id/index.php/litigasi

Litigasi, Vol. 17(1), 2016, 3256-3283

DOI: http://dx.doi.org/10.23969/litigasi.v17i1.97

pihak yang kemudian dibatasi oleh ketentuan yang sifatnya memaksa agar pelaksanaan hak dan kewajiban berlangsung secara proporsional. Apa yang terjadi dalam praktek merupakan konsekuensi logis dari pemahaman dan pola pikir yang salah kaprah, sehingga yang terjadi para pihak mengamankan dirinya dalam berhadapan dengan pihak lawannya yang isinya cenderung hanya menguntungkan dirinya sendiri tanpa menghiraukan pihak lawan.

Kesalahan mendasar dalam memahami folosofi asas kebebasan berkontrak ini harus segera diluruskan dan dikembalikan pada pemahaman yang sebenarnya, yaitu menempatkan para pihak dalam posisi yang setara dan proporsional. Tidak menempatkan para pihak untuk saling berhadapan, menjatuhkan bahkan mematikan. Dalam membuat kontrak dengan mitranya harus diupayakan untuk selalu memikirkan bagaimana agar kontrak itu memberi rasa aman, dan diuntungkan, sehingga mitra kontrak memperoleh hasil dan manfaat yang sama bagi para pihak. Oleh karenanya akan terbagun suatu situasi yang saling menghargai, menguntungkan, mengamankan tujuan para pihak sebagaimana yang tertuang dalam kontrak yang membawa pada situasi "win-win solution" . Dengan demikian penerapan asas kebebasan berkontrak hendaknya dikaitkan dengan kerangka pemahaman pasal-pasal yang lain, yaitu :

1. Pasal 1320 KUHPerdata mengenai syarat sahnya perjanjian

Copyright @ C 2016, LITIGASI, p-ISSN: 0853-7100; e-ISSN: 2442-2274 
Available online at: http://ejournal.unpas.ac.id/index.php/litigasi

Litigasi, Vol. 17(1), 2016, 3256-3283

DOI: http://dx.doi.org/10.23969/litigasi.v17i1.97

2. Pasal 1335 KUHPerdata, yang melarang dibuatnya kontrak tanpa causa atau dibuat berdasarkan suatu kausa yang palsu atau yang terlarang, dengan konsekkuensi tidak mempunyai kekuatan.

3. Pasal 1337 KUHPerdata yang menyatakan bahwa suatu sebab adalah terlarang, apabila dilarang oleh undang-undang, atau apabila berlawanan dengan kesusilaan atau ketertiban umum.

4. Pasal 1338 Ayat (3) KUHPerdata yang menetapkan bahwa kontrak harus dilaksanakan dengan itikad baik

5. Pasal 1339 KUHPerdata menunjuk terikatnya perjanjian kepada sifat kepatutan, kebiasaan dan undang-undang

6. Pasal 1347 KUHPerdata yang mengatur mengenai hal-hal yang menurut kebiasaan selamanya diperjanjikan.

Bila dibandingkan dengan asas kebebasan berkontrak di Belanda Pasal 6:2 NBW telah ditinggalkan dari konsep dalam Pasal 1338 atay (1) KUHPerdata kita, karena lebih berorientasi pada pentingnya "reasonabless and fairness" atau "kelayakan dan kepatutan" dalam melakukan perbuatan hukum khususnya berkaitan dengan kontrak. Oleh karenanya di Belanda asas kebebasan berkontrak diakui secara implisit namun dengan penekanan ramburambu kelayakan dan kepatutan. Dalam praktek di Indonesia kelayakan dan kepatutan dalam perjanjian itu adalah tidak melanggar norma-norma yang berlaku sebagaimana yang ditentukan dalam undang-undang, kebiasaan dan ketertiban umum. Hal ini sejalan dengan pemikiran Ridwan Khairandy bahwa

Copyright @ C 2016, LITIGASI, p-ISSN: 0853-7100; e-ISSN: 2442-2274 
Available online at: http://ejournal.unpas.ac.id/index.php/litigasi

Litigasi, Vol. 17(1), 2016, 3256-3283

DOI: http://dx.doi.org/10.23969/litigasi.v17i1.97

kebebasan berkontrak sudah mengalami pergeseran kearah kepatutan dan prinsip itikad baik untuk membuka peluang dalam penegakkan hukum kontrak dalam menutup sisi negatif asumsi-asumsi kebebasan berkontrak. Gagasan utama kebebasan berkontrak berkaitan dengan penekanan akan persetujuan dan maksud atau kehendak para pihak. Pandangan bahwa kontrak adalah hasil dari pilihan bebas (free choice), sehingga dianut faham bahwa tidak seorangpun terikat kepada kontrak sepanjang tidak dilakukan atas dasar adanya pilihan bebas untuk melakukan sesuatu. Mengenai kehendak dalam paradigma ini mengandung konsekuensi :

1. Hukum yang berlaku bagi mereka semata-mata berkaitan dengan maksud yang sebenarnya dari pihak yang berjanji

2. Maksud para pihak harus bertemu pada saat sebelum dibuatnya kontrak.

3. Hakim tidak memiliki kewenangan untuk mengisi celah dalam suatu kesepakatan dan tidak berdaya menghadapi kemungkinan hal yang tidak terduga, dan pihak yang berjanji bebas mengungkapkan pilihannya.

Dengan terjadinya pergeseran paradigma kebebasan berkontrak ke arah kepatutan (itikad baik), maka teori kehendak dengan pendekatan subjektifnya yang melekat pada paradigma kebebasan berkontrak mengalami pelemahan dan digantikan oleh pendekatan objektif. Dalam pandangan Ridwan Khairandy pendekatan objektif ini sudah sama-sama diterima dalam sistem common law dan civil law dengan perbedaan basis yang digunakan. Commom Law menggunakan basis bargain, sedangkan civil law dengan persesuaian

Copyright @ C 2016, LITIGASI, p-ISSN: 0853-7100; e-ISSN: 2442-2274 
Available online at: http://ejournal.unpas.ac.id/index.php/litigasi

Litigasi, Vol. 17(1), 2016, 3256-3283

DOI: http://dx.doi.org/10.23969/litigasi.v17i1.97

kehendak. Faktor objektif yang paling mungkin adalah bersandar kepada itikad baik yang mengalami banyak perkembangan (Yana Risdiana, 2016). Hal ini sejalan dengan apa yang dikemukakan oleh H.R. Daeng Naja bahwa itikad baik mengandung pemahaman bahwa para pihak tidak hanya terikat oleh ketentuan yang ada dalam perjanjian dan undang-undang, tetapi juga terikat oleh itikad baik dalam Pasal 1338 ayat (3) KUHPerdata. Itikad baik berarti bahwa kedua belah pihak harus berlaku terhadap yang lain berdasarkan kepatutan diantara orang-orang yang sopan, tanpa tipu daya, tanpa tipu muslihat, tanpa akalakalan, dan tidak hanya melihat kepentingan diri sendiri, tetapi juga kepentingan orang lain (Galuh Puspaningrum, 2015).

Oleh karenanya kedudukan penyalahgunaan keadaan sebagai faktor yang menyebabkan kehendak menjadi cacat, sangat penting dalam sistem hukum kontrak di Indonesia karena memberi ruang bagi penyelesaian kontrak dalam praktek disamping sebagai upaya mengisi kekosongan hukum di dalam KUHPerdata yang selama ini hanya diatur faktor-faktor yang menyebabkan kehendak menjadi cacad, yaitu kekhilafan, paksaan dan penipuan segbagaimana diatur dalam Pasal 1321 KUHPerdata, dan sebagai faktor yang keempat, yaitu penyalahgunaan keadaan yang timbul dari yurisprudensi di Belanda, merupakan input bagi perkembangan hukum kontrak di Indonesia sebagaimana diatur dalam Pasal II Aturan Peralihan UUD 1945 bahwa segala badan dan lembaga yang ada masih berlaku sepanjang belum ada badan atau lembaga yang baru.

Copyright @ C 2016, LITIGASI, p-ISSN: 0853-7100; e-ISSN: 2442-2274 


\section{SIMPULAN DAN SARAN}

\section{A. Simpulan}

1. Hubungan antara penyalahgunaan keadaan sebagai faktor yang menyebabkan cacad kehendak terhadap terjadinya kontrak adalah sangan penting, karena perjanjian terjadi dengan adanya kata sepakat, sehingga mengikat kedua belah pihak yang membuatnya. Kata sepakat seringkali menjadi dasar atas berlakunya kontrak, dimana untuk menentukan saat terjadinya kontrak adalah telah terjadinya persesuaian kehendak dari para pihak. Penyalahgunaan keadaan sebagai faktor yang menyebabkan kehendak pihak-pihak menjadi cacat selain kekhilafan, paksaan dan penipuan sebagaimana diatur dalam Pasal 1321 KUHPerdata mengakibatkan kontrak itu menjadi dapat dibatalkan, karena kontrak akan dapat dilaksanakan bila tidak ada kecacatan atau faktor yang mempengaruhinya.

2. Kedudukan penyalahgunaan keadaan sebagai faktor yang menyebabkan cacat kehendak dalam upaya mengisi kekosongan hukum dalam sistem hukum perjanjian di Indonesia adalah sangat penting, karena ada dalam Pasal 1320 KUHPerdata, yaitu harus adanya kata sepakat diantara para pihak. Apabila terjadi pengaruh yang tidak pantas atau pihak yang dipengaruhi tidak memberikan persetujuan dengan sepenuh keyakinannya, maka tidak ada persesuaian kehendak diantara para pihak. Keabsahan berkontrak dapat mencapai tujuannya bila para pihak mempunyai 
Available online at: http://ejournal.unpas.ac.id/index.php/litigasi

Litigasi, Vol. 17(1), 2016, 3256-3283

DOI: http://dx.doi.org/10.23969/litigasi.v17i1.97

bargaining power yang seimbang. Dalam praktek salah satu pihak memiliki posisi tawar yang lemah, dan tidak seimbang, sehingga pemerintah turut campur untuk melindungi pihak yang lemah dengan mengedepankan dan memperbanyak aturan-aturan yang sifatnya memaksa (dwingend recht), juga kebebasan berkontrak telah mengalami perubahan paradigma dan kepatutan (itikad baik) sebagaimana diatur dalam Pasal 1338 ayat (3) KUHPerdata, sebagai upaya mengisi kekosongan hukum kontrak berkaitan dengan penyalahgunaan keadaan sebagai faktor yang menyebabkan cacad kehendak yang keempat. Dengan demikian penyalahgunaan keadaan sangat penting artinya dalam mengisi kekosongan hukum kontrak di Indonesia dalam rangka mempersiapkan hukum kontrak dimasa yang akan datang.

B. Saran

1. Dalam rangka pembentukkan hukum perjanjian di Indonesia yang akan datang, kedudukan penyalahgunaan keadaan sebagai faktor yang menyebabkan cacad kehendak, menjadi persoalan penting karena dalam praktek telah terjadi, sehingga sangat dibutuhkan.

2. Dalam pembentukan hukum kontrsk yang akan datang perlu adanya pembatasan dan pengawasan terhadap asas kebebasan berkontak sebagaimana diatur dalam Pasal 1338 ayat (1) KUHPerdata.

Copyright @ 2016 , LITIGASI, p-ISSN: 0853-7100; e-ISSN: 2442-2274 
Available online at: http://ejournal.unpas.ac.id/index.php/litigasi

Litigasi, Vol. 17(1), 2016, 3256-3283

DOI: http://dx.doi.org/10.23969/litigasi.v17i1.97

\section{DAFTAR PUSTAKA}

\section{BUKU}

Ahmad Fikri Assegaf, 2014, Penjelasan Hukum Tentang Klausula Baku, Jakarta: Pusat Studi dan Kebijakan Indonesia.

Agus Yudha Hernoko, 2009, Hukum Perjanjian Asas Proporsionalitas Dalam Kontrak Komersial, Jakarta: Kencana Prenadamedia Group.

Galuh Puspaningrum, 2015, Hukum Perjanjian Yang Dilarang Dalam Persaingan Usaha. Yogyakarta: Aswaja Pressindo.

Salim HS, et al., 2006, Perancangan Kontrak dan Memorandum of Understanding (MoU), Jakarta: Sinar Grafika.

Sudikno Mertokusumo, 1987, Penyalahgunaan Keadaan, Kursus Hukum Perikatan Bagian III, Yogyakarta: Dewan Kerjasama IImu Hukum Belanda Dengan Indonesia Proyek Hukum Perdata.

Wawan Muhwan Hariri, 2011 , Hukum Perikatan Dilengkapi Hukum Perikatan Dalam Islam, Bandung: CV Pustaka Setia.

Yana Risdiana, 2016, Penafsiran Kontrak Komersial Antara Teks dan Konteks, Bandung: Cetakan Pertama, Iboeku Media IImu.

PERATURAN PERUNDANGAN

Kitab Undang-Undang Hukum Perdata

Copyright @ 2016, LITIGASI, p-ISSN: 0853-7100; e-ISSN: 2442-2274 